Available online at http://journal.ugm.ac.id/jifnp
INDONESIAN FOOD AND NUTRITION PROCRESS

Indonesian Food and Nutrition Progress, 2017, Vol. 14, Issue 1

\title{
Kinetic Degradation of Myristicin, Elemicin, and Safrole in Encapsulated Banda Nutmeg (Myristica fragrans Houtt) Oleoresin
}

\author{
Dewi Amrih ${ }^{*}$, Chusnul Hidayat, Pudji Hastuti \\ Department of Food and Agricultural Product Technology, Faculty of Agricultural Technology, Universitas \\ Gadjah Mada, Yogyakarta, Indonesia \\ ${ }^{*}$ Corresponding author, email address: dewi_amrih@yahoo.com
}

Received 23 Jan 2017; Accepted 12 May 2017; Published Online 15 May 2017

\begin{abstract}
Spices, in the form of oleoresin, have advantages as a flavoring agent. Nutmeg oleoresin compounds that play an important role in the formation of nutmeg flavor are myristicin, elemicin, and safrole. These compounds are not stable, so that the quality of oleoresin decreased easily. An alternative to overcome this problem is the encapsulation of oleoresin using spray drying techniques. The objective of this research was to evaluate the physicochemical properties of oleoresin with respect to the degradation of myristicin, elemicin, and safrole of nutmeg oleoresin. Microencapsulated nutmeg oleoresin was prepared using $12 \%$ WPC and $88 \%$ maltodextrin as encapsulate materials. It was stored in dark glass bottles at a various temperature, namely $30^{\circ} \mathrm{C}, 40^{\circ} \mathrm{C}, 50^{\circ} \mathrm{C}$, $60^{\circ} \mathrm{C}$, and $70^{\circ} \mathrm{C}$, for $0,4,7,10,14,21,28,35,42,49,56$ and 63 days. The content of myristicin, elemicin, and safrole were analysed. The results showed that myristicin, elemicin, and safrole in the encapsulated nutmeg oleoresin decreased during the storage until 28 days of storage and then they were relatively stable until 63 days. The activation energy of myristicin, elemicin, and safrole were $2.21 \mathrm{~kJ} / \mathrm{mol} \mathrm{K,} 2.71 \mathrm{~kJ} / \mathrm{mol} \mathrm{K}$ and 3.22 $\mathrm{kJ} / \mathrm{mol} \mathrm{K}$, respectively.
\end{abstract}

Keywords: nutmeg, oleoresin, microencapsulation, kinetics

\section{Introduction}

Oleoresin is a mixture of resin and essential oil that are obtained from the spices extraction. The use of spices in the oleoresin has an advantage such as the complete flavour or equal with the original spices so it can be used as a flavouring agent. However, oleoresin compounds are not stable during storage where it causes off-flavour. Therefore, it has to be protected.

Microencapsulation can protect oleoresin from damage and potentially change the liquid into a stable powder form, so it is easy to be applied and put in food systems (Wagner and Warthesen, 1995).
Spray drying is one of the microencapsulation technique that requires a material (encapsulate materials) to maintain the emulsion stability of oil or oleoresin during the drying process. Maltodextrin is a modified starch that can be used as an alternative of carrier materials (Reineccius, 1989). Besides maltodextrin, an encapsulant agent that can be used as carrier materials are whey protein concentrates (Hogan et al., 2001).

From the previous results the nutmeg oleoresin were containing of 39 compounds. Among the nutmeg oleoresin compounds, the most of dominant aromatic compounds were myristicin, elemicin, and safrole. These 
compounds have an important role in the nutmeg oleoresin as a flavouring agent (Krishnamoorthy and Rema, 2001; Purseglove et al., 1981).

Nutmeg oleoresin compounds in the encapsulated oleoresin change during the storage. Degradation of myristicin, elemicin, and safrole compounds may be predicted using Arrhenius model and it can be used to predict the shelf life of encapsulated nutmeg oleoresin. The objective of this research was to evaluate the changes in physicochemical properties with the approach of degradation myristicin, safrole, and elemicin nutmeg oleoresin compounds which then can be used in estimated the shelf life of encapsulated nutmeg oleoresin.

\section{Materials and Methods}

Mature Banda nutmeg (Myristica fragrans Houtt.) were obtained from Marikurubu village, Ternate Island, North Maluku Province. Maltodextrin (DE 10-19) and Whey Protein Concentrate (WPC) with the protein content $35-75 \%$.

\section{Preparation of Nutmeg Oleoresin}

Nutmeg oleoresin was obtained by a combine method of distillation-maceration. About $1.5 \mathrm{~kg}$ nutmeg flour, which was passed 20 mesh sieve, was added into the boiling kettle that has been equipped with condenser and clavenger. Subsequently, $6 \mathrm{~L}$ water was added. The mixture was heated for $4 \mathrm{~h}$, and steam was condensed by cooling water at 4$7^{\circ} \mathrm{C}$. The remaining water in essential oil was removed by passing the oil through sodium sulfate anhydrous. The remaining nutmeg powder residue in the distillation was dried. Subsequently, oleoresin in nutmeg residue was extraction by maceration method using methanol. Nutmeg essential oil was weighed to determine the extraction yield using distillation method.

\section{Preparation of Encapsulated Nutmeg Oleoresin}

Maltodextrin (15.84\%) and WPC (2.16\%) were added into a mixture of distilled water $(80 \%)$ and nutmeg oleoresin (2\%). It was then emulsified by ultra-turrax homogenizer for $30 \mathrm{~min}$ at $6400 \mathrm{rpm}$. After that, emulsion were dried in spray drying at an inlet temperature of $160^{\circ} \mathrm{C}$, outlet temperature of $60-78^{\circ} \mathrm{C}$, and air flow rate of $300 \mathrm{~mL} / \mathrm{h}$ (Assagaf et al., 2012).

\section{Degradation of Nutmeg Oleoresin Compounds of Encapsulated Nutmeg Oleoresin}

As much as $30 \mathrm{~g}$ of the encapsulated nutmeg oleoresin was placed in a closed dark bottle and then stored in an incubator at various storage temperature conditions, namely $30^{\circ} \mathrm{C}, 40^{\circ} \mathrm{C}, 50^{\circ} \mathrm{C}, 60^{\circ} \mathrm{C}$ and $70^{\circ} \mathrm{C}$. Samples were taken at $0,4,7,10,14,21,28$, $35,42,49,56$ and 63 days to determine the decrease in nutmeg oleoresin aroma compounds and the organoleptic flavour intensity.

\section{Analysis of Encapsulated Nutmeg Oleoresin Compounds}

This analysis was performed by GC-MS method. About $2 \mathrm{~g}$ of the encapsulated nutmeg oleoresin was added into $10 \mathrm{~mL}$ chloroform. It was sonicated for 4-5 $\mathrm{min}$ and filtered. The filtrate was further analyzed by Gas Chromatography-Mass spectrophotometry (GC-MS) model 5975B Agilent $6890 \mathrm{~N}$ MSD. The initial temperature was $80^{\circ} \mathrm{C}$ for $2 \mathrm{~min}$, then it was raised to $325^{\circ} \mathrm{C}\left(10^{\circ} \mathrm{C} / \mathrm{min}\right)$ and maintained for $1 \mathrm{~min}$. $\mathrm{GC}$ injector at the temperature of $300^{\circ} \mathrm{C}$ and the pressure of 9.38 psi using Helium gas type were used. GC was equipped with a HP-5ms column $5 \%$ phenyl methyl siloxane $(30 \mathrm{~m}$ length, $250 \mu \mathrm{m}$ diameter and $0.25 \mu \mathrm{m}$ thickness). GC was also associated with MSD 
Transfer Line Heater at $280^{\circ} \mathrm{C}$, detector voltage $1411.8 \mathrm{~V}$ and scan mass at $25-800$ $\mathrm{m} / \mathrm{z}$.

\section{Kinetics Data Analysis}

Nutrient degradation can be calculated in the same way by microbe inactivation (Toledo, 2007). The kinetics theory for the nutrient degradation during heating or degradation in the number of microbe during heating followed the first order kinetics (Singh and Heldman, 2001).) While Labuza and Riboh (1982) states that most of material quality deterioration reactions take place in zeroorder and first-order reaction.

Kinetics is the treatment of materials parameter due to the treatment of temperature level to time function. In this research could be interpreted that the kinetics theory of fishbone hardness degradation follows equation:

$$
\frac{d C}{d t}=k \cdot C^{n}(1)
$$

where $C$ is materials concentration (in this research is value of bone hardness obtained from level of maximal depress force $\left(F_{\max }\right)$ with units of Newton), $k$ represent the reaction rate constant, $\mathrm{n}$ is the order reaction (in this research is using the first order $(n=1)$ and $\mathrm{t}$ is time in minute. Eq. 1 can be altered into form:

$$
\frac{d C}{C}=k d_{i}(2)
$$

If this equation be integrated then obtained:

$$
\begin{aligned}
& -\int_{C_{0}}^{C} \frac{d C}{C} \int_{0}^{t} d(3) \\
& \ln _{C}^{C}=k t_{(4)} \\
& \frac{C}{C_{0}}=e^{-k . t}
\end{aligned}
$$

Assess the $k$ at Eq. 5 represent the constant rate from change of bone hardness and determinable by making plot the relationship between $\ln (\mathrm{C} / \mathrm{Co})$ and time $(\mathrm{t})$ in Cartesian graph. To determine the temperature influence on constant rate of bone hardness changes ( $\mathrm{k}$ ), used by Arrhenius equation (Eq. $6)$.

$$
k=A e^{\frac{A E}{R T}}
$$

Where $A$ can be substituted into:

$$
k=k_{o} e^{-\frac{A E}{R T}(7)}
$$

Eq. 8 can be changed into the equation:

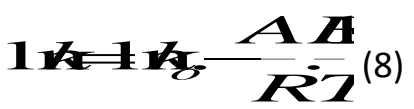

And from Eq. 9 can be applied in a linear equation.

From several values of $k$ at some particular temperature, hence can be described a relation graph the $k$ value with the temperature. From Eq. 8 is obtained linear regression of In $\mathrm{k}$ vs $1 / \mathrm{T}$ that gives straight line curve for Arrhenius Equation. From that equation will be obtained slope which is represent of $A E / R$ value so $A E$ can be determined. While the value of In $k$ at the $1 / T=0$ hence will have the value equal to $\ln k_{0}$. $\mathrm{R}$ is gas constant, equal to $8.314 .10^{-3} \mathrm{~kJ} / \mathrm{mol}$ $\mathrm{K}$ (Giannakourou and Taoukis, 2006).

\section{Results and Discussion}

Degradation Kinetics of Aromatic

\section{Compounds}

The encapsulated nutmeg oleoresin compounds decreased during the storage. It is suggested that aromatic ether group compounds are suspected as the most determination of nutmeg flavour. The dominant compounds in the aromatic ether group are including myristicin, elemicin, and safrole (Krishnamoorthy and Rema, 2001; Purseglove et al., 1981).

The storage of the encapsulated nutmeg oleoresin was performed for 63 days. The aromatic ether compounds decreased during storage until 28 days. Further increase 
in storage time they did not decrease and relatively stable until 63 days. Thus the change in decreasing of oleoresin compounds reached the equilibrium, since the system was a close system. It is suggested that the aromatic ether compounds were not fully protected during microencapsulation process, so that it was easy to diffuse into the environment.

Kinetics Degradation of Myristicin. Myristicin is the main compound in nutmeg olereoresin and it is an aromatic ether group. Myristicin reduction during storage is presented in Fig. 1. An increase in storage temperature from $30^{\circ} \mathrm{C}$ to $70^{\circ} \mathrm{C}$ resulted in an increase in the degradation rate of myristicin compound in the encapsulated nutmeg

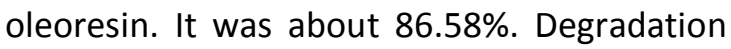
of myristicin followed first order reaction.

Table 1 shows that an increase in the storage temperature from $30^{\circ} \mathrm{C}$ to $70^{\circ} \mathrm{C}$ resulted in an increase in the $k$ value of myristicin degradation from 0.0231 up to 0.0431 . It means that the reactions were taken place more quickly.

By obtaining of the $k$ value, then could be made the graph of In $k$ versus inverse absolute temperature (1/T) as shown in Fig. 2. So it could be determined the value of activation energy (Ea). Activation energy is a function of temperature $(\mathrm{T})$ and constant of the reaction change rate $(\mathrm{k})$.

The value of the activation energy in myristicin compound was $2.21 \mathrm{~kJ} / \mathrm{mol} \mathrm{K}$. This activation energy could be used as parameter to determine the reaction rate and then used to estimate the shelf life of encapsulated nutmeg oleoresin samples. At the lower temperatures, the Ea value was greater so that the reaction rate was slower, otherwise the lower Ea showed the reaction was rapid occurred at the high temperatures.

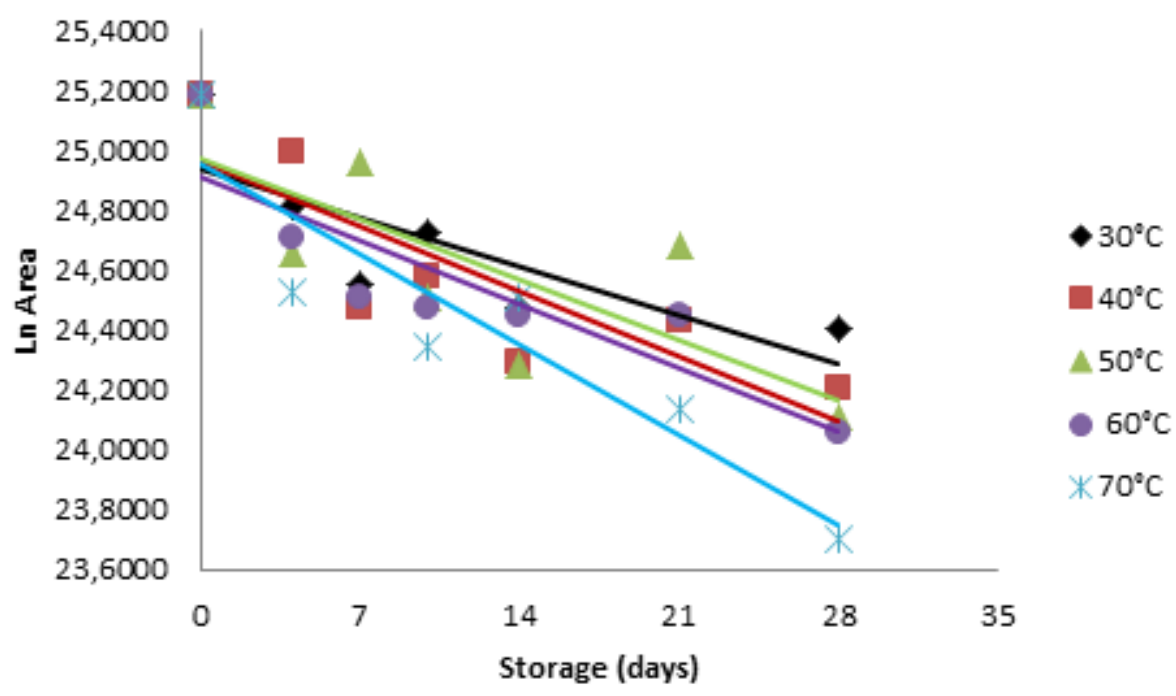

Fig. 1 The decrease of myristicin compounds in encapsulated nutmeg oleoresin as the function of time

Table 1. Constant of degradation rate $(k)$ of myristicin

\begin{tabular}{cccc}
\hline Temperature $\left({ }^{\circ} \mathrm{C}\right)$ & Linear Equations & $\mathrm{R}^{2}$ & $\mathrm{k}$ \\
\hline 30 & Ln Area $=-0.0231 \mathrm{t}+24.9354$ & 0.6412 & 0.0231 \\
40 & Ln Area $=-0.0310 \mathrm{t}+24.9662$ & 0.7016 & 0.0310 \\
50 & Ln Area $=-0.0289 \mathrm{t}+24.9729$ & 0.5881 & 0.0289 \\
60 & Ln Area $=-0.0305 \mathrm{t}+24.9127$ & 0.7684 & 0.0305 \\
70 & Ln Area $=-0.0431 \mathrm{t}+24.9541$ & 0.8472 & 0.0431 \\
\hline
\end{tabular}




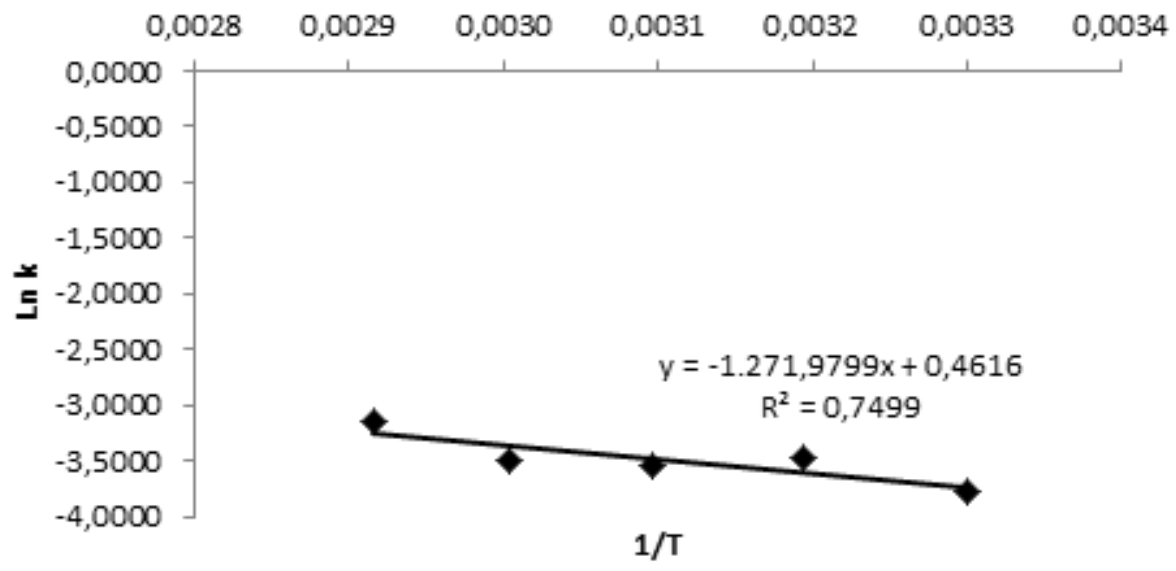

Fig. 2 The value of $\mathrm{Ln} k$ as function of inverse Absolute temperature (1/T) in Myristicin compounds.

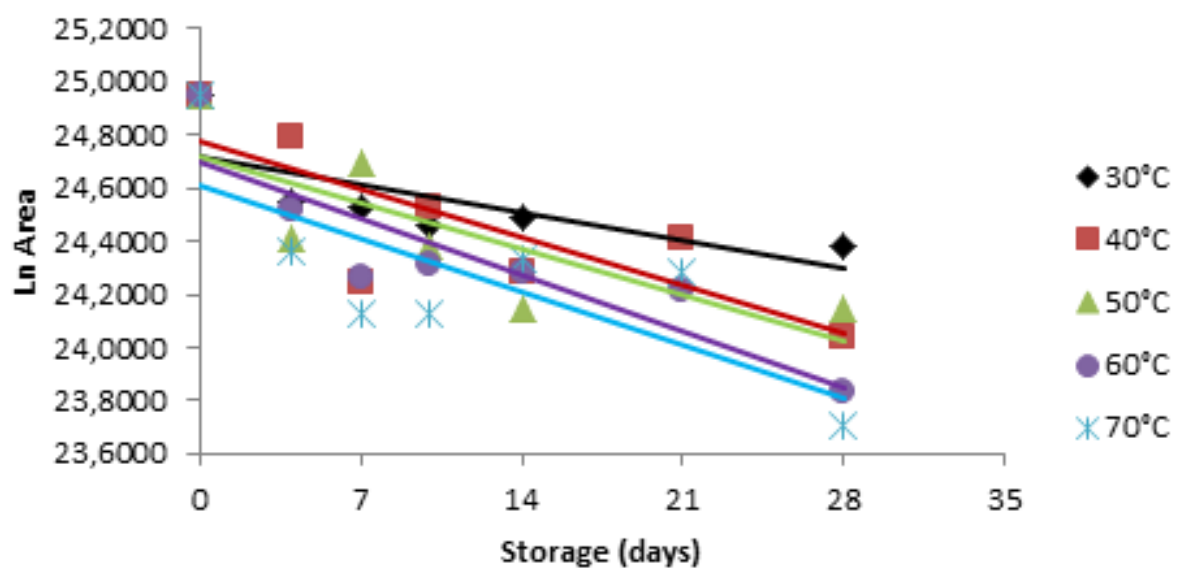

Fig 3. The decrease of elemicin compound in encapsulated nutmeg oleoresin as function of time

Kinetics Degradation of Elemicin. Elemicin is an aromatic ether compound group that dominant besides myristicin. The reduction graph of elemicin compounds during storage was presented in Fig. 3. Degradation kinetics of elemicin in first order.

With the higher temperature of encapsulated nutmeg oleoresin storage from $30^{\circ} \mathrm{C}$ to $70^{\circ} \mathrm{C}$, the decreased rate of elemicin compounds was greater which reached $104.03 \%$. The degradation rate constants (k) was presented in Table 2 .

Table 2 shows that the higher of the temperature storage of encapsulated nutmeg oleoresin from $30^{\circ} \mathrm{C}$ to $70^{\circ} \mathrm{C}$ was obtained the greater of $\mathrm{k}$ values up to 0.0304. It was showed that the increase of the temperature storage so that the reaction was faster or the reduction rate of elemicin compounds in encapsulated nutmeg oleoresin samples was higher. 
Table 2. Constant of degradation rate $(k)$ of elemicin

\begin{tabular}{cccc}
\hline Temperature $\left({ }^{\circ} \mathrm{C}\right)$ & Linear Equations & $\mathrm{R}^{2}$ & $\mathrm{k}$ \\
\hline 30 & Ln Area $=-0.0149 \mathrm{t}+24.7159$ & 0.5491 & 0.0149 \\
40 & Ln Area $=-0.0260 \mathrm{t}+24.7763$ & 0.6439 & 0.0260 \\
50 & Ln Area $=-0.0249 \mathrm{t}+24.7168$ & 0.6097 & 0.0249 \\
60 & Ln Area $=-0.0304 \mathrm{t}+24.7032$ & 0.7874 & 0.0304 \\
70 & Ln Area $=-0.0287 \mathrm{t}+24.6124$ & 0.5744 & 0.0287 \\
\hline
\end{tabular}

After obtained the $\mathrm{k}$ values, then was made of In $k$ versus inverse absolute temperature (1/T) graphics as shown in Fig. 4. to get the activation energy (Ea). Activation energy is a function of temperature $(T)$ and constant of the reaction change rate $(k)$. The activation energy in elemicin compound was $2.71 \mathrm{~kJ} / \mathrm{mol} \mathrm{K}$. At lower temperatures, the Ea value was higher so that the reaction rate was slower, otherwise the lower Ea showed the reaction that was occurred fast at the high temperatures.

Degradation Kinetics of Safrole. Aromatic ether compounds group that was dominant beside myristicin and elemicin was safrole. The reduction graphics of safrole compound in encapsulated nutmeg oleoresin samples during storage was presented in Fig. 5. Degradation kinetics of elemicin was first order.

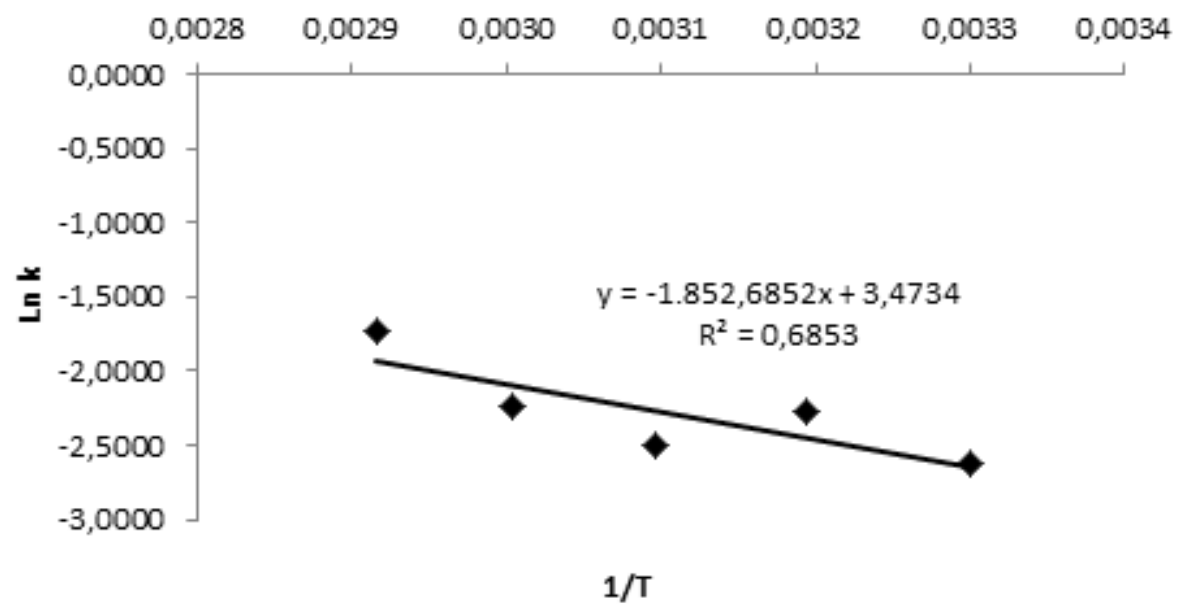

Fig. 4 The value of $L n k$ as function of inverse Absolute temperature $(1 / T)$ in elemicin compounds 


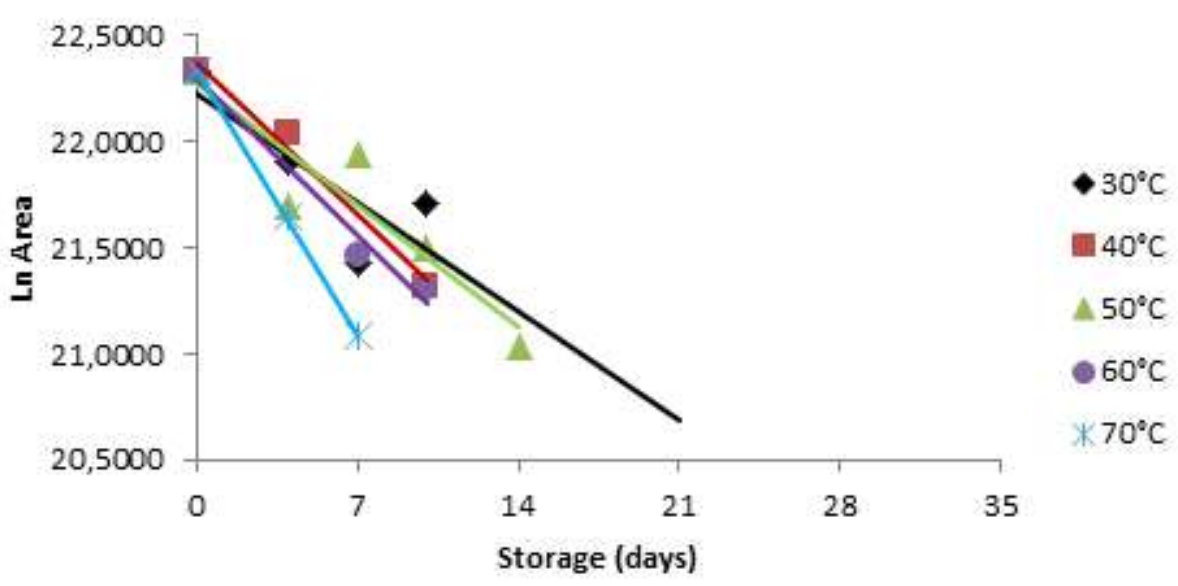

Fig. 5 The decrease of Safrole compounds in encapsulated nutmeg oleoresin as the function of Time

Fig 5. shows that the higher of storage temperature encapsulated nutmeg oleoresin from $30^{\circ} \mathrm{C}$ to $70^{\circ} \mathrm{C}$ so that the reduction rate of safrole compound was higher, which reached $142.68 \%$. From the graph above could be seen the value of constants (k) reduction rate was shown in Table 3.

From Table 3 was known that the $k$ value was greater up to 0.1774 with the increase of storage temperature in encapsulated nutmeg oleoresin sample up to $70^{\circ} \mathrm{C}$. With the higher of $\mathrm{k}$ value, so that the reaction was faster or the reduction rate of safrole compound in encapsulated nutmeg oleoresin samples was higher. After obtained the $k$ values, then was made of In $k$ versus inverse absolute temperature $(1 / T)$ graphics as shown in Figure 3.6 to get the activation energy (Ea). Activation energy is a function of temperature $(T)$ and constanta of the reaction change rate $(k)$.

Table 3. Constant of degradation rate (k) of safrole

\begin{tabular}{|c|c|c|c|}
\hline Temperature $\left({ }^{\circ} \mathrm{C}\right)$ & Linear Equations & $\mathrm{R}^{2}$ & $\mathrm{k}$ \\
\hline 30 & Ln Luas $=-0.0731 \mathrm{t}+22.2266$ & 0.6837 & 0.0731 \\
\hline 40 & Ln Luas $=-0.1022 \mathrm{t}+22.3700$ & 0.9851 & 0.1022 \\
\hline 50 & Ln Luas $=-0.0824 t+22.2798$ & 0.8527 & 0.0824 \\
\hline 60 & Ln Luas $=-0.1059 t+22.2998$ & 0.9793 & 0.1059 \\
\hline 70 & Ln Luas $=-0.1774 t+22.3358$ & 0.9991 & 0.1774 \\
\hline
\end{tabular}

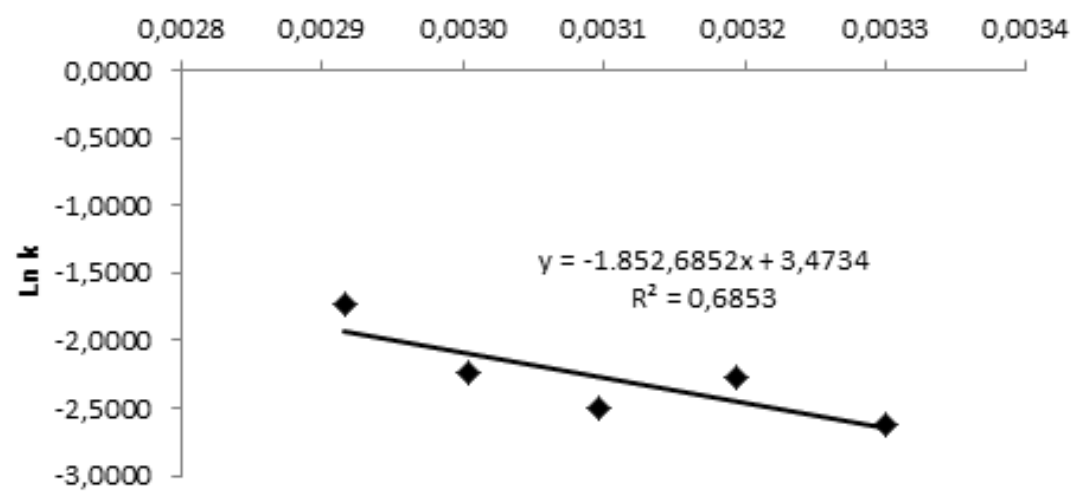

$1 / \mathrm{T}$

Fig. 6 The value of $L n k$ as function of absolute temperature inverse (1/T) in the safrole compound. 
The value of the activation energy in safrole compounds was $3.22 \mathrm{~kJ} / \mathrm{mol} \mathrm{K}$. At lower temperatures, the Ea value was higher so that the reaction rate was slower, otherwise the lower Ea showed the reaction that was occured fast at the high temperatures.

The compounds of aromatic ether groups that were dominant in encapsulated nutmeg oleoresin samples, ie myristicin, elemicin, and safrole during the storage period up to 28 days, obviously the content of compounds were decreased. The value of the activation energy between myristicin, elemicin, and safrole compounds was shown in Table 4.

Table 4. Activation energy of aromatic ether

\begin{tabular}{lc}
\hline Compounds & Ea $(\mathrm{kJ} / \mathrm{mol} \mathrm{K})$ \\
\hline Myristicin & 2,21 \\
Elemicn & 2,71 \\
Safrole & 3,22 \\
\hline
\end{tabular}

From Table 4 was known that in three aromatic ether compound groups, the fastest reduction reaction was myristicin, which myristicin had the lowest activation energy in comparison with other compounds. This is influnced by myristicin compounds have lowest flash point $\left(90^{\circ} \mathrm{C}\right)$. Flash point for elemicin and safrole is $92.6^{\circ} \mathrm{C}$ and $97^{\circ} \mathrm{C}$, respectively. So, myristicin is more easily to loss compound compared the other aromatic compunds because low flash point so that activation energy was too small.

\section{Conclusion}

Aromatic ether compound groups that dominant in the nutmeg were myristicin, elemicin, and safrole for the storage period of encapsulated nutmeg oleoresin sample had decreased at the beginning of storage until the day of 28 . After the day of 28 , the content of myristicin, elemicin, and safrole compounds until the end of storage period were stable relatively. The value of activation energy in myristicin compound was 2.21 $\mathrm{kJ} / \mathrm{mol} \mathrm{K}$, elemicin and safrole compounds were $2.71 \mathrm{~kJ} / \mathrm{mol} \mathrm{K}$ and $3.22 \mathrm{~kJ} / \mathrm{mol} \mathrm{K}$, respectively.

\section{References}

Assagaf, M., Hastuti, P., Hidayat, C., and Supriyadi. 2012. Perbandingan Ekstraksi Oleoresin Biji Pala (Myrictica fragrans Houtt) Asal Maluku Utara Menggunakan Metode Maserasi dan Gabungan Distilasi-Maserasi. J. Agritech 32(3)

Giannakourou, M.C. and Taoukis, P.S. 2006. Systematic Application of Time Temperature Integrators as Tools for Control of Frozen Vegetable Quality. J. Food Sci. 67(6):2221-2228.

Hogan, S. A., B. F. McName, E. D. O'Riordan, and M. O'Sullivan. 2001. Microencapsulating Properties of Whey Protein Concentrate 75. Journal of Food Science. 66 (5): 675-680.

Krishnamoorthy, B. and Rema, J.. 2001. Nutmeg and mace. In "Handbook of Herbs and Spices". ed. Peter, K.V. Woodhead Publishing, Abington, Cambridge, UK.

Labuza, T.P. and Riboh, D. 1982. Theory and Application of Arrhenius Kinetics to the Prediction of Nutrient Losses in Foods [Degradation, Keeping, Quality, Temperature, Quality Controls, Analysis, Models]. Food Technology. 36:66-74.

Purseglove, J. W., Brown, E. G., Green, C. L., and Robbins, S. R. J. 1981. Spices Vol.1. Longman Scientific and Technical. Copublished in the United States with John Wiley and Sons, Inc., New York.

Reineccius, G. A. 1989. Carbohydrates for Flavor Encapsulation. Food Technology. 45:144-149. 
Singh, R.P. and Heldman, D.R. 2001. "Introduction to Food Engineering. Academic Press, London.

Toledo, R.T. 2007. "Fundamentals of Food Process Engineering, Springer, USA.
Wagner, Lori A. and Warthesen, Joseph J. 1995. Stability of Spray-Dried Encapsulated Carrot Carotenes. Journal of Food Science. 60(5):1048-1053. 